I denne spalten presenteres tidligere publiserte artikler, mange av dem fra Tidsskriftet.

Artiklene er utvalgt og blir introdusert av Ole Didrik Lærum.

\title{
Å være på god fot
}

Fungerer man godt sammen med noen, er man «på godfot med» vedkommende. Føttene er viktige, det har alle som går med ulike former for fotplager smertelig fått erfare. Men hvor stor kan en fot bli - og kan de bli for store?

Den amerikanske sangeren, jazzpianisten og multitalentet Edward «Fats» Waller var større og tyngre enn de fleste. | 1930-årene hadde han et lite band som spilte swingjazz full av rytme og humor. En av hans kjente låter har tittelen «Your feet's too big». I teksten forteller han selvbiografisk om at hver gang han fikk ros her i livet så kom et stort «men»: Føttene dine er for store. Ofte hadde folk et tillegg om at «jeg kan ikke hjelpe deg når føttene er for store». På en måte som samtidig er morsom og ganske sår fremstiller han hvordan det er å være forskjellig fra andre.

Pediateren Jørgen Knudtzon og Torbjørg M. Johannessen tok på vegne av foreningen Storfoten opp fotstørrelse i en artikkel i Tidsskriftet i 1991. De kom med en del oppsiktsvekkende opplysninger om normalvariasjonen i størrelse og at føttene kan ha en uavhengig posisjon i forhold til resten av kroppen. Riktignok er størrelsen hos voksne oftest i samsvar med kroppshøyden, men føttene begynner faktisk å vokse mellom et halvt og ett og et halvt år før kroppens sterkeste vekstperiode setter inn.

Har man svært store føtter, kan det føre til flere problemer. Noen får rett og slett komplekser av å ha så lange føtter og passer på å skjule dem så godt de kan. Enkelte unngår derfor konsekvent å gå ut på dansegulvet. Tendensen er at personer med svært store føtter velger seg tilsvarende partnere. Det andre problemet er at det er vanskelig å få kjøpt store nok sko. I verste fall kan det føre til betydelige fotplager fordi man går i for små sko. Derfor ble det i sin tid dannet en egen forening for personer med store føtter, både til felles trøst og for å skaffe passende fottøy.

Hovedkonklusjonen i denne artikkelen, og som jeg støtter helhjertet, er at store føtter ikke er noe patologisk. Men at skoene produseres for små, er et stort problem. Forfatterne har også en viktig underliggende konklusjon: Vi må ta vare på og respektere mangfoldet hos menneskene som en ressurs og ikke være intolerante eller definere det som et problem. Derfor er artikkelen vel verdt et nytrykk.

Ole Didrik Lærum

ole.laerum@gades.uib.no

Ole Didrik Lærum er professor (adj.) ved Københavns Universitet og professor emeritus ved Universitetet i Bergen.

\section{Foreningen Storfoten}

\author{
Skostørrelse, høyde og alder ved menarke
}

\author{
Jørgen Knudtzon \\ Barneklinikken \\ Rikshospitalet \\ 0027 Oslo \\ Torbjørg M. Johannessen \\ Foreningen Storfoten \\ Postboks 274 \\ 7001 Trondheim
}

\section{Knudtzon J, Johannessen TM.}

\section{Size of the foot}

in relation to age at menarche

Tidsskr Nor Lageforen 1991; 111: 3638-9

A slight negative correlation $(\mathrm{r}=-0.198)$ was found between age at menarche and size of shoe in 106 women from a Norwe- gian organization for persons using shoe sizes larger than 41 . The correlation between stature and size of shoe was smaller $(r=0.086)$. These findings are discussed with respect to normal growth of the foot and body stature. Since pubertal growth of the foot occurs before the pubertal growth spurt, it is unlikely that oestrogen treatment for tall stature will affect foot length to any degree. The authors also discuss psychological and physical problems related to large feet.

Hos 106 kvinner i foreningen Storfoten som bruker skonummer større enn 41 , var det en svak negativ korrelasjon mellom skonummer og alder ved menarke $(r=-0,198)$, mens den positive korrelasjonskoeffisienten med kroppshøyde bare var 0,086. Funnene diskuteres med utgangspunkt i den normale veksten av foten $0 \mathrm{~g}$ kroppen for ovrig. Siden foten når sin endelige lengde tidligere enn slutthøyden, vil veksthemmende behandling ved stor høyde sannsynligvis ikke påvirke fotens endelige størrelse nevneverdig. Det foreligger derfor ingen medisinsk indikasjon for å forsøke å påvirke pubertet og vekst med utgangspunkt i fotens sluttlengde. Artikkelen avsluttes med en kort orientering om foreningen Storfoten, for å belyse de fysiske og psykologiske problemene som er forbundet med det å ha spesielt store fotter. 
Storfoten er en norsk interesseorganisasjon for personer med store føtter. Skoforretninger forhandler vanligvis sko i størrelser opptil 41 for kvinner og 46 for menn. Personer som trenger større sko, har derfor store praktiske problemer med å skaffe riktig skotøy.

Ved hjelp av en spørreskjemaundersøkelse har vi kartlagt skostørrelsen (skonummer) til kvinnelige medlemmer av foreningen Storfoten, og studert forholdet i relasjon til alder, høyde og alder ved menarke (første menstruasjon).

\section{Materiale}

Et anonymt spørreskjema ble sendt til 300 betalende medlemmer av foreningen sommeren 1989. Det ble blant annet spurt om alder, kjønn, høyde, skonummer, alder for første menstruasjon, eventuell veksthemmende behandling, høyde til samboer og skonummer til samboer. I alt 124 svar ble mottatt. 11 menn, tre kvinner som hadde fått veksthemmende behandling, og fire kvinner yngre enn 20 år ble tatt ut av undersøkelsen. Studien er basert på de gjenværende 106 kvinnene.

Korrelasjonsfaktorer og p-verdier er beregnet ved hjelp av PC-statistikkpakken Statgraphics versjon 3.0 (enkel regresjon).

Tabell 1 Alder, høyde, skonummer, alder ved menarke og innbyrdes korrelasjonskoeffisienter (r) og p-verdier for kvinner i foreningen Storfoten

\begin{tabular}{|c|c|c|c|c|}
\hline & $\begin{array}{l}\text { Gjennom- } \\
\text { snitt } \pm \text { SEM } \\
\text { (spredning) }\end{array}$ & Korrelasjoner & r-verdi & p-verdi \\
\hline Alder (år) & $\begin{array}{c}47,0 \pm 1,3 \\
(20-83)\end{array}$ & Mot høyde & $-0,26$ & 0,007 \\
\hline Høyde (cm) & $\begin{array}{l}179,0 \pm 0,5 \\
(169-195)\end{array}$ & $\begin{array}{c}\text { Mot menarke } \\
\text { Mot skonummer }\end{array}$ & $\begin{array}{l}0,086 \\
0,439\end{array}$ & $\begin{array}{l}0,390 \\
0,001\end{array}$ \\
\hline Skonummer & $\begin{array}{l}43 \pm 0,08 \\
(41,5-46)\end{array}$ & $\begin{array}{c}\text { Mot menarke } \\
\text { Mot alder }\end{array}$ & $\begin{array}{r}-0,198 \\
0,079\end{array}$ & $\begin{array}{l}0,049 \\
0,423\end{array}$ \\
\hline Alder ved menarke (år) & $\begin{array}{c}13,6 \pm 0,11 \\
(10,5-16,5)\end{array}$ & Mot alder & 0,165 & 0,099 \\
\hline
\end{tabular}

\section{Resultater}

I tabell 1 summeres funnene for alder, høyde, skonummer og alder ved menarke, og det angis korrelasjonskoeffisienter og p-verdier for sammenhenger mellom disse. Kvinnenes alder korrelerte negativt med deres høyde, men det var ingen signifikant korrelasjon til skonummer eller alder ved menarke (tab 1, fig 1).

Det var en positiv korrelasjon mellom skonummer og høyde (tab 1). Den negative korrelasjonskoeffisienten mellom skonummer og alder ved menarke var større enn den positive korrelasjonskoeffisienten mellom høyde og alder ved menarke (tab 1, fig 1).

Kvinnenes høyde og skonummer viste en signifikant korrelasjon med samboers høyde $(182,1 \pm 0,68$, gjennomsnitt \pm SEM $)$ og skonummer $(43,5 \pm 0,17)$, med korrelasjonskoeffisienter på henholdsvis 0,256 $(\mathrm{p}<0,026)$ og $0,758(\mathrm{p}<0,001)$.

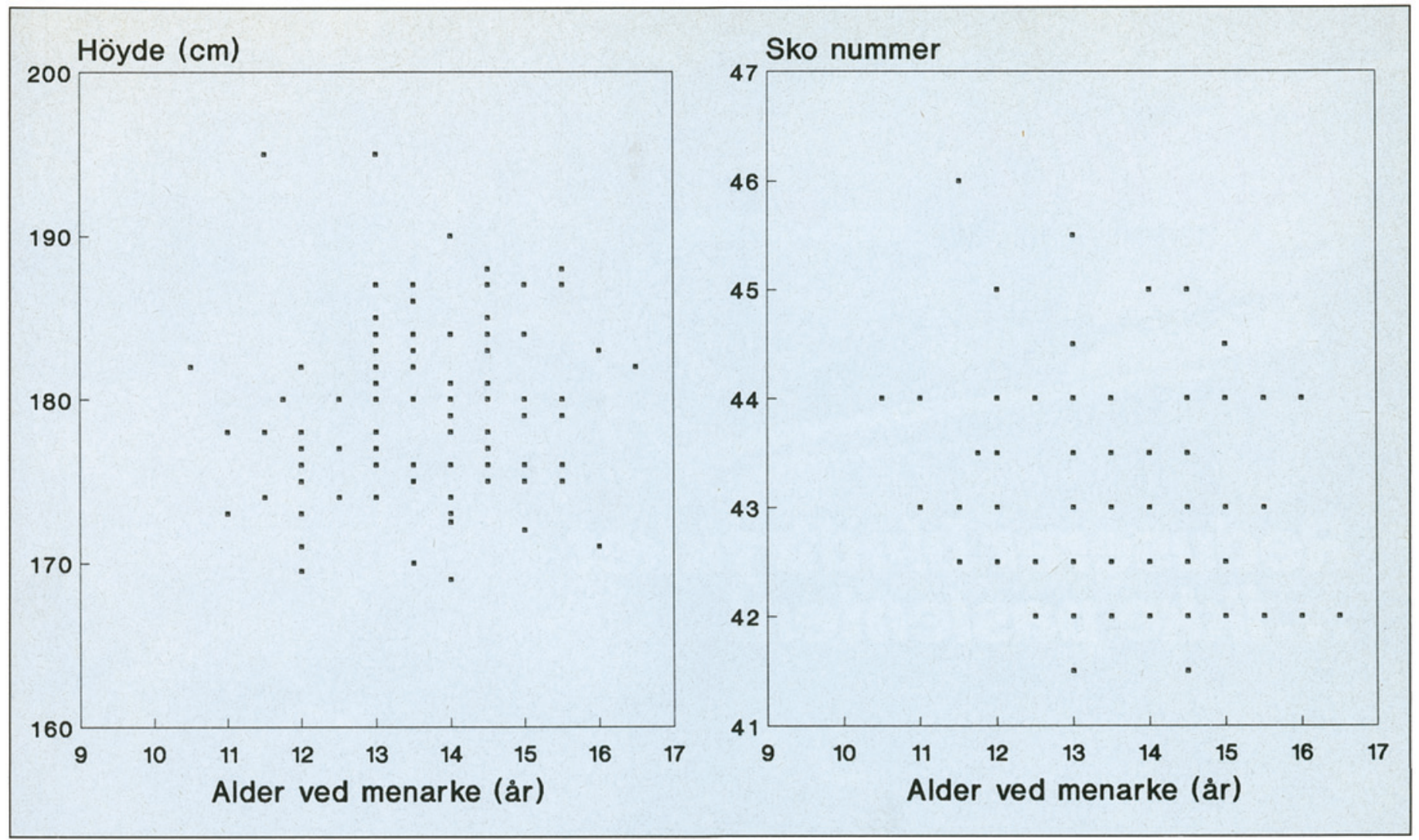

Figur 1 Høyde og skonummer relatert til alder ved menarke hos kvinner i foreningen Storfoten. Alder ved menarke viser en meget svak, men statistisk signifikant negativ korrelasjon (tab 1) med skonummer, men ikke med kroppshøyde 


\section{Diskusjon}

I løpet av dette århundre har den norske befolkningen vist en stadig større slutthøyde (den sekulære tendensen) mens alder ved menarke har sunket (1). Det var ingen korrelasjon $\mathrm{i}$ vår studie mellom kvinnenes alder og alder ved menarke (tab 1), men materialet er for lite til å vurdere hvorvidt den sekulære tendensen har stoppet opp. Kroppshøyden blir som kjent lavere med alder, og den negative korrelasjon mellom alder og høyde kan forklares ved at kvinnene ble bedt om å oppgi deres nåværende høyde, og ikke deres høyde ved f.eks. 20 års alder.

\section{Høyden til samboere/ektefeller}

Ikke uventet var det en positiv korrelasjon mellom kvinnenes høyde og høyden til deres ektefeller og samboere, som tegn på at høye kvinner lever sammen med høye menn. Imidlertid var høyden til kvinnene i Storfoten relativt sett betydelig større (+ 2,5 SD) enn høyden til deres ektefeller $(+0,6 \mathrm{SD})$.

\section{Kroppshøyde og pubertet}

Som ventet var kroppshøyden ikke korrelert med alder ved menarke. Dette kan forklares ved at en tidlig pubertet gir en kraftigere pubertetsvekst enn en sen pubertet, men samtidig avsluttes veksten tidligere. Den totale veksten ved tidlig pubertet blir derfor den samme som veksten prepubertalt og pubertalt ved sen pubertet (2). Dette brukes klinisk til å forutsi barns slutthøyde ut fra alder og høyde ved start av pubertet i den såkalte ICP- (infancy, childhood, puberty) vekstmodellen (2).

\section{Fotens størrelse}

Skonummer var naturlig nok sterkt korrelert med kroppshøyde. Den negative korrelasjonskoeffisienten mellom skonummer og alder ved menarke var større enn den positive korrelasjonskoeffisienten mellom kroppshøyde og alder ved menarke (tab 1). Det er utarbeidet egne percentilkurver for fotlengde i relasjon til alder (3). Føttene modnes tidligere enn andre deler av kroppen. Fotens pubertetsspurt starter 6-18 måneder før pubertetsspurten for kroppshøyden, og fotens vekst avsluttes tilsvarende tidligere (3). Korrelasjonskoeffisienten på -0,198 mellom skonummer og alder ved menarke kan kanskje antyde at friske lange kvinner med en tidligere pubertet tenderer til å ha større føtter enn lange kvinner med senere pubertet, som følge av en kraftigere pubertetsspurt. Tilsvarende kan man kanskje tenke seg at en patologisk sen pubertet som følge av hypogonadisme, som vil tendere til å øke kroppens ekstremiteter i retning av mer eunukoide proporsjoner (4), bare i liten grad vil påvirke fotens vekst fordi foten er tidligere utvokst.

Høye foreldre med store føtter er naturlig nok opptatt av at deres barn skal unngå de samme problemene. Siden føttene er tidligere utvokst enn kroppen for øvrig, vil veksthemmende behandling av barn med stor høyde neppe ha noen signifikant virkning på føttenes størrelse. Det foreligger ingen medisinsk indikasjon for å forsøke å påvirke pubertet og vekst med utgangspunkt i fotens sluttlengde.

\section{Foreningen Storfoten}

Når personer med store føtter danner en egen forening, som i Norge i dag teller over 1300 registrerte medlemmer, er det grunn for helsepersonell å se nærmere på de problemene som opptar foreningen. Storfoten har søkt om å bli tatt opp som medlem i Funksjonshemmedes fellesorganisasjon, men fått avslag.
I utgangspunktet er det ikke føttene det er noe galt med, men skoene. Imidlertid fører problemene med å skaffe riktig skotøy til en rekke tilleggsproblemer, og foreningen anfører en egen type «storfotpersonlighet» som «en robust og tøff type», eller «en som unngår dansegulvet og gjemmer føttene $o g$ sko under bordet». Erfaringene i foreningen viser at stor høyde, store føtter og problemer med å finne passende skotøy både i størrelse og utseende, kan føre til alvorlige psykiske belastninger, i enkelte tilfeller også til sosial isolasjon og uførhet. Anskaffelse av spesialskotøy kan medføre betydelige merutgifter uten at foreningen har oppnådd refusjon i kjøp av skotøy på lik linje med spesialsydde ortopediske sko ved andre fotlidelser. I praksis fører bruk av skotøy i feil størrelse til en rekke fysiske plager av fot, legg og rygg.

Individer med svært store føtter har, på samme måte som ekstremt korte og lange personer, ingen livstruende lidelse. Erfaringene viser imidlertid at det er viktig at helsepersonell tar disse tilstandene alvorlig for å forhindre ytterligere fysiske og psykiske plager. Foreningen Storfoten arbeider for øvrig aktivt for et bedre tilbud av skotøy i store størrelser og øket støtte og toleranse i samfunnet for individer med store føtter.

\section{Litteratur}

1. Brundtland G Harlem, Liestøl K, Walløe L. Height, weight and menarcheal age of Oslo schoolchildren during the last 60 years. Ann Hum Biol 1980; 7: 307-22.

2. Karlberg J, Fryer JG, Engström I, Karlberg P. Analyses of linear growth using a mathematical model II. From 3 to 21 years of age. Acta Pediatr Scand Supp11987; 337: 12-29.

3. Anderson M, Blais M, Green WT. Growth of the normal foot during childhood and adolescence. Length of the foot and interrelations of foot, stature, and lower extremity as seen in serial records of children between 1-18 years of age. Am J Phys Anthropol 1956; 14: 287-308.

4. Brook CGD. Management of delayed puberty. BMJ 1985; 290: 657-8. 